\title{
64-Towards teaching undergraduate-level disciplinary writing in English majors: A genre-based approach
}

\section{Aysel SARICAOĞLU1}

APA: Sarıcaoğlu, A. (2022). Towards teaching undergraduate-level disciplinary writing in English majors: A genre-based approach. RumeliDE Dil ve Edebiyat Araştırmaları Dergisi, (26), 1024-1038. DOI: $10.29000 /$ rumelide.1074517.

\begin{abstract}
Teaching students disciplinary writing skills is important in supporting them to develop a disciplinary identity, to become a member of their scientific communities, and to be academically and professionally more successful. Disciplinary writing practices are often implemented at the graduate level where students are familiarized with the processes of creating knowledge and the forms of written products within their disciplines. However, at the undergraduate level, disciplinary writing instruction is not a common practice in most higher education institutions in Turkey. This study addresses disciplinary writing needs of junior-level students in English Language and Literature (ELL) and English Language Teaching (ELT) and seeks to contribute to our understanding of how we can assist students' disciplinary writing skills at an early stage in their undergraduate studies. It describes an undergraduate-level research-informed and genre-based disciplinary writing course for the ELL and ELT disciplines. The course aims to equip students with disciplinary knowledge and writing skills in line with the requirements of their departmental writing tasks. The course is described with a focus on learning objectives, teaching units, weekly structure, sample teaching materials and activities, and assessment of students' written work. The challenges associated with developing and teaching this course are addressed, and some considerations that teachers must think about when implementing and evaluating the course are given.
\end{abstract}

Keywords: Disciplinary writing, genre-based approach, undergraduate students, English language and Literature, English Language Teaching

\section{İngiliz dili programlarında lisans düzeyinde disipliner yazma eğitimi üzerine: Tür odaklı yaklaşım}

\section{$\ddot{O} \mathbf{z}$}

Öğrencilere disipliner yazma becerilerinin kazandırılması, disiplin kimliklerini oluşturmalarını, bilimsel toplulukların bir üyesi olmalarını, akademik ve mesleki açıdan daha başarılı olmalarını desteklemek açısından önemlidir. Disipliner yazma uygulamaları genellikle lisansüstü düzeyinde bilgi üretme ve yazılı ürünlere dönüştürme şeklinde uygulanmaktadır. Ancak, lisans düzeyinde, disipliner yazma eğitimi Türkiye'deki çoğu yükseköğretim kurumunda yaygın bir uygulama değildir. Bu çalışma, İngiliz Dili ve Edebiyatı ile İngilizce Öğretmenliği programlarındaki lisans öğrencilerinin disipliner yazma ihtiyaçlarını ele almaktadır ve öğrencilerin disipliner yazma becerilerini lisans eğitimlerinin erken bir aşamasında nasıl geliştirebileceğine dair onlara nasıl destek olabileceğimizi anlamamıza katkıda bulunmayı amaçlamaktadır. Bu çalışmada İngiliz Dili ve Edebiyatı ile İngilizce Öğretmenliği programlarındaki lisans öğrencilerini, bölüm derslerinde yaptıkları yazma ödevlerinin

Dr. Öğr. Üyesi, Ankara Sosyal Bilimler Üniversitesi, Yabancı Diller Fakültesi, İngiliz Dili ve Edebiyatı (Ankara, Türkiye), aysel.saricaogluaygan@asbu.edu.tr, ORCID ID: 00oo-0002-5315-018X [Araştırma makalesi, Makale kayıt tarihi: 07.01.2022-kabul tarihi: 20.02.2022; DOI: 10.29000/rumelide.1074517]

Adres | Address

RumeliDE Dil ve Edebiyat Araştırmaları Dergisi Osmanağa Mahallesi, Mürver Çiçeği Sokak, No:14/8 Kadıköy - İSTANBUL / TÜRKIYE 34714 e-posta: editor@rumelide.com

RumeliDE Journal of Language and Literature Studies Osmanağa Mahallesi, Mürver Çiçeği Sokak, No:14/8 Kadıköy - ISTANBUL / TURKEY 34714 tel: +90 $5057958124,+902167730616$

phone: +90 $5057958124,+902167730616$ 
gereklilikleri doğrultusunda, disiplin bilgisi ve disipliner yazma becerileri ile donatmayı amaçlayan, tür odaklı bir disipliner yazma dersi tanıtılmaktadır. Ders ile ilgili, öğrenme hedefleri, üniteler, haftalık plan, örnek öğretim materyalleri ve etkinlikleri ve değerlendirme çerçevesinde bilgi verilir. $\mathrm{Bu}$ dersi geliştirilmesinde ve uygulanmasında yaşanılan ya da yaşanılabilecek zorluklar ele alınır ve öğretmenlerin dersi uygularken ve değerlendirirken düşünmesi gereken bazı hususlara yer verilir.

Keywords: Disipliner yazma, tür odaklı yaklaşım, lisans öğrencileri, İngiliz Dili ve Edebiyatı, İngilizce Öğretmenliği

\section{Introduction}

Every academic discipline consists of a specific community of individuals who have shared interest in that discipline and aims to gain disciplinary knowledge (Lave \& Wegner, 1991). Disciplinary communities have their own way of creating knowledge and sharing it with their community members in written forms. Thus, disciplinary writing skills are important for individuals to interact with their scientific communities, to construct a disciplinary identity, to become a member of their communities, and to be academically and professionally more successful.

Disciplinary writing practices are often implemented at the graduate level where students are familiarized with the processes of creating knowledge and the forms of written products within their disciplines. However, at the undergraduate level, disciplinary writing instruction that would prepare students for the demands of their departmental writing tasks by engaging them in disciplinary reading and producing discipline-specific texts is unfortunately not a common practice in most higher education institutions around the world, including those in Turkey. Current departmental academic writing courses in English majors underscore the urgency of acculturating students into their disciplinary writing conventions starting from the undergraduate level. They are mostly designed around general writing skills and general topics and are repetitive of the writing courses that students take at language schools prior to their departmental courses. This is understandable given the challenges presented by disciplinary writing instruction, which requires both knowledge of disciplinary content and academic writing. Few academic staff members have expertise and experience in both domains. However, early access to disciplinary writing practices is important in helping students develop disciplinary identities, better manage their departmental writing tasks and achieve higher academic success. For this reason, teaching academic writing in a discipline-specific way is worth the time and effort required.

This study addresses disciplinary writing needs of junior-level students in English majors and seeks to contribute to our understanding of how we can assist students' disciplinary writing skills at an early stage in their undergraduate studies. It argues against general teaching of academic writing skills to undergraduate-level students of English majors and for a discipline-specific writing course that is grounded in research and disciplinary content and writing skills. To this end, it describes an undergraduate level research-informed and genre-based disciplinary writing course for English majors. The course aims to equip students with disciplinary knowledge and writing skills addressing their needs in line with the requirements of their departmental writing tasks.

The paper starts with the background of the study identifying the problem associated with current academic writing practices in English majors and the need for disciplinary writing practices and continues with reviewing existing pedagogical and scholarly work on disciplinary writing. The second part describes the development of an undergraduate-level disciplinary writing course for English majors

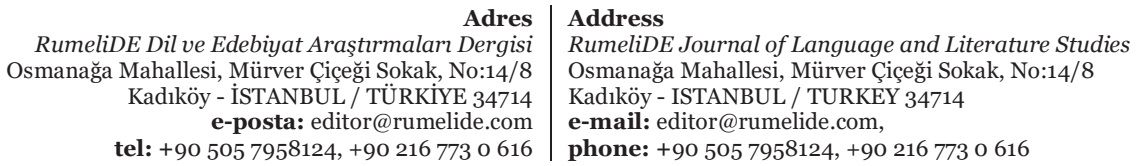


1026 / RumeliDE Journal of Language and Literature Studies 2022.26 (February)

Towards teaching undergraduate-level disciplinary writing in English majors: A genre-based approach / A. Sarıcaoğlu (pp. 1024-1038)

with a focus on learning objectives, weekly structure, sample teaching materials and activities, writing tasks assigned, and assessment of students' written work. The paper concludes with the challenges associated with developing the disciplinary writing course for undergraduate-level students in English majors and some considerations that teachers must think about when implementing and evaluating the course.

\section{Background}

\subsection{Academic writing practices in English majors in Turkey}

Academic writing is a highly essential skill for university students since academic achievement is largely determined by written performance in several disciplines. Students' writing-related challenges in fact predict their academic success in higher education institutions with English medium of instruction (EMI) (Kamasak, Sahan, \& Rose, 2021). Written assignments at university require disciplinary writing skills, which are beyond the basic or generic academic writing skills, making writing one of the most challenging skills for university students especially in EMI contexts. The ongoing struggle to successfully meet the writing demands of college-level assignments convinces students that they are bad at writing, and as a result, they develop negative identities as writers (Fernsten \& Reda, 2011). Indeed, we, as content area teachers, are partly to blame for such resistance, or failure, since it is our responsibility to provide supportive pedagogies to assist our students in becoming competent writers who are equipped with disciplinary knowledge and writing skills.

Undergraduate level English Language and Literature (ELL) and English Language Teaching (ELT) programs in Turkey offer students writing courses within their first years in their departments. For example, the curriculum of the ELT programs as developed by the Council of Higher Education in Turkey includes two first-year academic writing courses: Writing Skills I for the Fall semester and Writing Skills II for the Spring semester. In Writing Skills I, students practice paragraph-level writing in different genres such as narration, summary, review, or letter. In Writing Skills II, students practice process writing, self- and peer-evaluation, composing and reporting (chromeextension://efaidnbmnnnibpcajpcglclefindmkaj/viewer.html?pdfurl=https\%3A\%2F\%2Fwww.yok.gov. tr\%2FDocuments\%2FKurumsal\%2Fegitim_ogretim_dairesi\%2FYeni-Ogretmen-Yetistirme-Lisans-

Programlari\%2FIngilizce_Ogretmenligi_Lisans_Programi.pdf\&clen=177691\&chunk=true see the course descriptions by YÖK). Although ELL programs do not have to follow the curriculum suggested by YÖK, they also offer writing courses designed in a similar way. The ELL program at Social Sciences University of Ankara, for example, also focuses on different types of academic essay such as descriptive, narrative, compare-contrast, cause-effect or argumentative (https://obs.asbu.edu.tr/oibs/bologna/index.aspx?lang=tr\&curOp=showPac\&curUnit=5\&curSunit=1 o32see the course description).

Current departmental academic writing courses of ELL and ELT programs in Turkey are far from meeting the discipline-specific writing needs of students since they are designed in a generic way, teaching basic writing skills or the general academic essay. Ineffectiveness of such generic writing courses is obviously a shared concern among Turkish scholars, as reflected by their perceptions regarding the writing problems that students experience. Faculty members from Boğaziçi University, for example, report that students cannot "transfer the writing knowledge they gain in their academic writing courses to other departmental courses" (Altınmakas \& Bayyurt, 2019, p. 101). It is highly probable that this lack of transfer is a result of the mismatch or the lack of a connection between what practices are

\footnotetext{
Adres $\mid$ Address

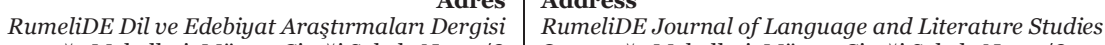

Osmanağa Mahallesi, Mürver Çiçeği Sokak, No:14/8 $\quad$ Osmanağa Mahallesi, Mürver Çiçeği Sokak, No:14/8

Kadıköy - İSTANBUL / TÜRKIYE 34714 Kadıköy - ISTANBUL / TURKEY 34714

e-posta: editor@rumelide.com e-mail: editor@rumelide.com,

tel: +90 5057958124, +902167730616 phone: +90 505 7958124, +90 2167730616
} 
employed in academic writing classes and what writing tasks students are required to perform within their departmental courses. Teaching the general academic essay in ELL and ELT departmental writing courses is of relatively limited benefit since essay is not the only genre that students are required to produce in their courses. In ELL, for example, in addition to argumentative essays, students are also expected to write reviews, reflections, research papers (Altınmakas \& Bayyurt, 2019) as well as literary analysis papers. Thus, departmental writing courses in ELL and ELT programs should be designed in a way that adheres to disciplinary content and writing tasks.

\subsection{Disciplinary writing practices}

Academic writing is a community practice, done with the purpose of communicating with groups of communities from certain scientific disciplines (Hyland, 2000; Swales, 1990). Individuals from a specific disciplinary community share interest in that discipline and engage in disciplinary communication to gain and share disciplinary knowledge (Lave \& Wegner, 1991). Discipline-specific (or disciplinary) writing is defined more specifically focusing on the forms of writing in a discipline, in other words the types of written products that individuals are engaged in. For example, individuals in engineering disciplines commonly produce reports while individuals in literature produce literary analyses. Such group of texts with similar discoursal features that specific academic communities produce are referred to as genres (Hyland, 2007). Following this definition, a genre-based writing pedagogy views writing as a social practice and focuses on the intersection between the communicative purpose of writing, meaning and discoursal features of texts, audience addressed, and context (Derewianka, 2003).

Discipline-specific instruction is not only valued by students, but it is also positively benefiting their learning outcomes (Baik \& Greig, 2009; Gimenez, 2008). It has been investigated in a range of disciplines. Baik and Greig (2009) implemented a content-based English language program with firstyear Architecture students to help them learn the subject matter, develop discipline-specific language, and learn the practices of the discipline. They found out that the regular participants of the program "performed considerably better in both the European Architecture subject and in their studies in the subsequent year" (p. 413). In another implementation, Kutevaa (2013) asked graduate students from four different disciplines (i.e., archaeology, history, literature, and media studies) to compare and contrast texts from the dissertation and research article genres and explored how this genre analysis task increased students' genre awareness. Employing a workshop approach, Cargill et al. (2018) implemented a four-week (16 hours) "Preparing to Write an International Science Article" course with graduate students from science and technology disciplines. The course addressed "identifying takehome messages from data, selecting target journals, and writing to meet the criteria of editors and referees" as well as "strategies for developing discipline-specific English skills" (p. 13), which resulted in increased confidence of students for publication.

Literature on discipline-specific writing includes several case studies in which particular attention has been paid to the process of how novice scholars (i.e., graduates) engage in rhetorical reading of research articles and contribute new knowledge to their disciplines through publications (e.g., Cheng, 2008; Flowerdew, 2000; Li, 2006). Findings from these studies reveal the kinds of difficulties graduates experience at various stages of publication and their coping strategies. They are also valuable in informing our pedagogical decisions and processes to assist novice scholars in contributing knowledge to their disciplines.

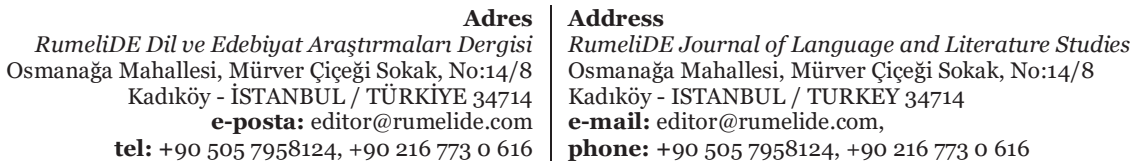


What is rare in the literature is studies on genre-based writing practices in ESL/EFL teaching at the undergraduate level. In one study, Chen and Su (2011) explored to what extent a seven-week genrebased instruction facilitated students' skills in summarization overall and specifically in content, organization, vocabulary and language use. Their genre-based instruction included providing an explicit summary template, guided practice, and relevant lexical and grammatical patterns. The instruction enhanced students' summary performance overall, but facilitated their content development and rhetorical organization more than vocabulary and language use. In a more recent study, Uzun and Topkaya (2020) implemented genre-based instruction and feedback in an English Literature I course with pre-service English teachers who produced literary analysis essays. According to their results, students' performance in writing a literary analysis essay steadily improved throughout the semester while the type of the feedback provided (i.e., direct feedback supported by a rationale versus indirect feedback supported by a rationale) did not influence their writing development.

Answering the question of "how we should approach the teaching and learning of disciplinary practices" (Johns \& Swales, 2002, p.18) for English majors, this study proposes a disciplinary writing course for undergraduate level students in the ELL and ELT disciplines. Teaching disciplinary writing to ELL and ELT students requires to make important decisions about course design. Because junior students do not have the disciplinary knowledge base at this level necessary to create and contribute new knowledge to their disciplines, the course should rather target that students gain disciplinary knowledge and join scholarly conversations by producing the forms of written texts that are a regular part of their disciplines. In this course, writing tasks should serve not only the purpose of teaching discipline-specific writing skills but also the purpose of teaching disciplinary content, a powerful combination that can prepare students for their departmental requirements and for higher academic achievement.

\section{Development of an undergraduate-level disciplinary writing course for English majors}

\subsection{Course description}

To better respond to students' departmental writing needs, the undergraduate-level academic writing course is designed around disciplinary writing skills for the students of English Language Teaching (ELT) and English Language and Literature (ELL) programs. Based on inquiry and research, this genrebased course aims to help students gain an understanding of what topics or issues are addressed within their disciplines, what problems are tried to be solved, what multiple perspectives exist, and how scholarly discussions are held. The course also aims to help students to join the scholarly conversations by crafting their own positions, creating arguments based on what they have already learned, using evidence, and considering counterarguments.

Learning objectives of the course are determined as the following:

- to demonstrate familiarity with disciplinary topics,

- to demonstrate an understanding of the key elements of argumentation,

- to effectively formulate arguments and support their arguments through evidence,

- to demonstrate an understanding of the key elements of reflective writing, argumentative writing, and literary analysis writing,

\footnotetext{
RumeliDE Dil ve Edebiyat Araşttrmaları Dergisi Osmanağa Mahallesi, Mürver Çiçeği Sokak, No:14/8 Kadıköy - İSTANBUL / TÜRKIYE 34714 e-posta: editor@rumelide.com

Address

RumeliDE Journal of Language and Literature Studies

Osmanağa Mahallesi, Mürver Çiçeği Sokak, No:14/8

Kadıköy - ISTANBUL / TURKEY 34714 tel: +90 $5057958124,+902167730616$

-mail: editor@rumelide.com,

phone: +90 $5057958124,+902167730616$
} 
- to find reliable sources, to critically evaluate sources, and to synthesize information from the sources appropriately,

- to accurately make in-text citations and create reference lists using the target citation format,

- to demonstrate an understanding of process-based writing as a series of stages as composing, editing, and revising, and

- to produce advanced level texts in different disciplinary genres.

The content of the course is structured in five units as (1) understanding sourced-based writing, (2) understanding argumentation, (3) understanding reflective writing, (4) understanding argumentative essay writing, and (5) understanding literary analysis writing. Source-based writing and argumentation are practiced first since they are central to the following writing tasks. Source-based writing and argumentation are practiced at the sentence and paragraph levels, and no writing tasks are given for these two units. Reflective writing, essay writing, and literary analysis writing are practiced via a writing task following an instructional week on each genre. Table 1 illustrates the structuring of the course around five units and presents a (flexible) weekly schedule that can be followed.

Table 1. Course structure and suggested weekly schedule

\begin{tabular}{l|l} 
Week 1 & Introduction to the course
\end{tabular}

Unit 1- Understanding Source-based Writing

\begin{tabular}{l|l} 
Week 2 & $\begin{array}{l}\text { In-text citation rules } \\
\text { Hands-on practice }\end{array}$ \\
Week 3 & $\begin{array}{l}\text { End-of-text citation rules } \\
\text { Hands-on practice }\end{array}$
\end{tabular}

Unit 2- Understanding Argumentation

\begin{tabular}{l|l} 
Week 4 & $\begin{array}{l}\text { The role of argument in research and academic writing } \\
\text { Elements of argumentation }\end{array}$
\end{tabular}

Week 5

Identifying \& developing arguments

Hands-on practice

Unit 3- Understanding Reflective Writing

\begin{tabular}{l|l} 
Week 6 & $\begin{array}{l}\text { Purposes and essential features of reflection } \\
\text { Analysis of sample written reflections }\end{array}$ \\
Week 7 & $\begin{array}{l}\text { Task 1: Written reflections } \\
\text { First drafts }\end{array}$ \\
Week 8 & $\begin{array}{l}\text { Feedback on written reflections } \\
\text { Revisions \& Final drafts }\end{array}$
\end{tabular}

Unit 4- Understanding Argumentative Essay Writing

\begin{tabular}{l|l} 
Week 9 & $\begin{array}{l}\text { Structuring of an argumentative essay } \\
\text { Analysis of sample argumentative essays }\end{array}$
\end{tabular}

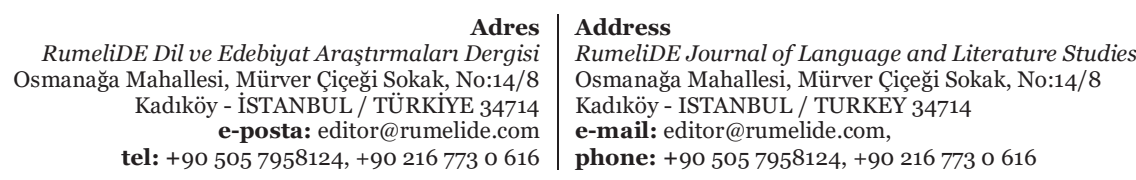


1030 / RumeliDE Journal of Language and Literature Studies 2022.26 (February)

Towards teaching undergraduate-level disciplinary writing in English majors: A genre-based approach / A. Sarıcaoğlu (pp. 1024-1038)

\begin{tabular}{|c|c|}
\hline Week 10 & $\begin{array}{l}\text { Task 2: Argumentative ELL/ELT essays } \\
\text { First drafts }\end{array}$ \\
\hline Week 11 & $\begin{array}{l}\text { Feedback on Argumentative ELL/ELT essays } \\
\text { Revisions \& Final drafts }\end{array}$ \\
\hline \multicolumn{2}{|c|}{ Unit5- Understanding Literary Analysis Writing } \\
\hline Week 12 & $\begin{array}{l}\text { Structuring of a literary analysis } \\
\text { Analysis of sample literary analyses }\end{array}$ \\
\hline Week 13 & $\begin{array}{l}\text { Task 3: Literary analyses } \\
\text { First drafts }\end{array}$ \\
\hline Week 14 & $\begin{array}{l}\text { Feedback on Literary analyses } \\
\text { Revisions \& Final drafts }\end{array}$ \\
\hline
\end{tabular}

The course starts with source-based writing not because it is a common requirement in college-level written assignments but because it is a core academic literacy skill that helps students acquire new knowledge and socialize within their communities of practice (Cumming, Lai, \& Cho, 2016). Thus, proficiency in disciplinary writing requires the mastery of source-based writing, which is cognitively challenging especially for undergraduate L2 writers. To this end, it is necessary to provide explicit instruction on and learning opportunities for source-based writing rather than expecting students to self-learn it (Wette, 2019).

The course continues with argumentation, which is covered separately from argumentative essay writing because of the fundamental importance of argumentation in higher education, as well expressed by Andrew's (2010) following remarks:

It is important to be able to argue rationally in a civilized society, and students in higher education will be expected to be able to do so - both within their courses and in the wider world. Second, advancement in knowledge often comes via argument. A case is proved; a dispute is opened up and then solved; a new hypothesis is posited; academics, students, and everyone else are asked to look at an old problem in a new way. Third, argument is about clarification as well as persuasion. Wellargued speeches, essays, position papers, or research papers bring a sharper sense of meaning and significance to an issue. Fourth, argument can be enjoyable - and universities and colleges are spaces in which argument is encouraged and where it can flourish. (p. 1)

Argumentation as a higher-order intellectual skill is involved in several genres that students engage with in ELL and ELT disciplines and is critical for academic success. The ability to produce good argumentative texts has been found to be the best predictor of academic success during the first highereducation year (Geiser and Studley, 2002). "The most successful undergraduates tend to be those who can argue well, in speech and/or writing, whatever their discipline" (Andrews, 2015, p. 52). Closely tied to critical thinking skills, argumentation skills are often hard for students. Turkish higher-education students, for example, "cannot construct well-established arguments" and "they base their ideas and arguments on over-generalized assumptions" (Altınmakas \& Bayyurt, 2019, p. 101). This is partly because students do not receive enough instructional support at university as argumentation is not taught explicitly in undergraduate courses (Mitchell \& Riddle, 2000). From a pedagogic perspective, this course aims to provide students with explicit instruction on argumentation and ample opportunities to develop their argumentation skills.

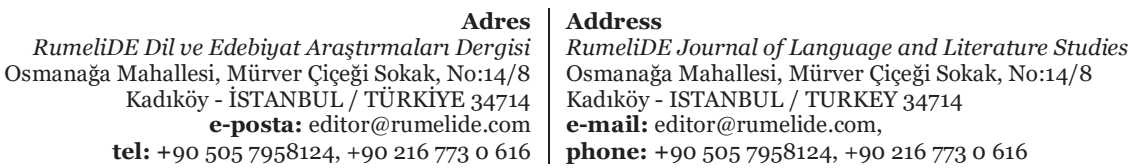


The third unit of the course focuses on reflective writing (also referred to as reflective essay or reflective journal by practitioners). Although often assigned as a writing task, reflective writing is infrequently explicitly taught in classes (Pasternak \& Rigoni, 2015). Reflective writing allows students to develop their ability to think critically and deliberately, to reflect on personal thoughts and experiences associated with learning, to increase their self-awareness, and to take responsibility of their learning (Penso, Shoham, \& Shiloah, 2001). It is widely used across different disciplines including EFL education (Cheng, 2017), teacher education (Lai \& Calandra, 2010), or ELL (Altınmakas \& Bayyurt, 2019), thus can be viewed as a discipline-specific writing task for the ELL and ELT disciplines.

The fourth unit of the course is argumentative essay writing. Argumentative essay is one of the most common genres undergraduate students write (Mei, 2006). Because students in the ELL and ELT programs are often asked to take a position on disciplinary matters in their written assignments, argumentative essay writing is a relevant task to their disciplines as it is already practiced in the ELL and ELT programs in Turkey (Altınmakas \& Bayyurt, 2019). Wingate (2012) argues that academic teachers and students do not have a solid understanding of argumentation because specific requirements of argumentation and the nature of an argumentative essay vary greatly across disciplines. Thus, argumentative essay writing should be studied in a discipline-specific way, which this course aims to do.

The course ends with the genre of literary analysis/criticism. Literary criticism is a discipline-specific writing practice that aims to examine and interpret a literary work (Bressler, 2010). It is commonly used as a writing task not only in ELL programs but also in ELT programs (see Uzun \& Topkaya, 2020). Because critically analyzing a work of literature also builds upon argumentation, developing persuasive interpretative arguments is difficult for students (Marshall, 2000), and they basically produce literary analyses in a plot summary form (Persky, Daane, \& Jin, 2003). Research has shown that explicit instruction on interpretative arguments about literature allows students to write higher quality literary analyses including more textual evidence to support their literary interpretations (Lewis \& Ferretti, 2011).

\subsection{Sample teaching and learning materials and activities}

Source-based writing can be first practiced inductively by enhancing autonomous learning. Authentic teacher-designed materials such as simplified and shortened versions of published research articles in ELL/ELT can be used for the citation analysis tasks having students, in pairs or groups, figure out intext and end-of-text citation rules and then check their self-generated rules with the lists provided by the teacher. The citation format, APA (commonly used in ELT) or MLA (commonly used in ELL), can be selected by the teacher in line with discipline practices. Students should then engage in both receptive and productive tasks practicing in-text and end-of-text citations. Receptive tasks can involve, for example, asking students to identify and fix the citation errors in the given texts, to identify the type of citation (e.g., paraphrase or direct quotation), or to identify the type of resource cited (e.g., book, journal article, etc.). In the productive tasks, students can be engaged in tasks that require them to practice both in-text and end-of-text citations. For example, they can be asked to write small paragraphs on a given topic making citations from the given sources. It is important that students practice both their direct quoting skills and paraphrasing skills as well as summarizing skills. It is also important to make use of different types of sources for the purposes of practicing end-of-text citation rules.

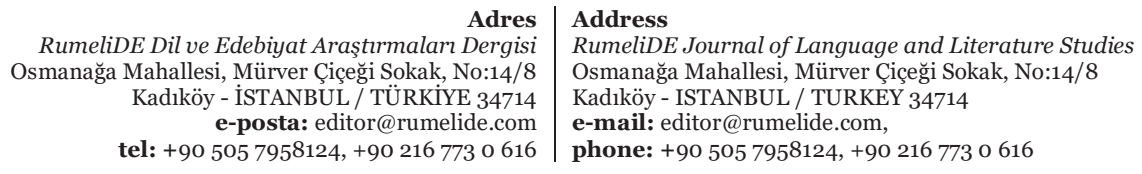


When teaching reflective writing, Hatton and Smith's (1995) framework can be used as it clearly differentiates reflective writing from descriptive writing. It well illustrates the effectiveness of reflective writing across three types: descriptive reflection (i.e., description of the event with some justification efforts or recognition of alternative viewpoints), dialogic reflection (i.e., analytical discourse with oneself exploring the experience with judgments and explanations), and critical reflection (i.e., awareness of multiple perspectives and the influence of historical and socio-political contexts) (Pasternak \& Rigno, 2015).

For their ELL/ELT argumentative writing task, students can be given a list of disciplinary argumentative topics to choose from or they can be given flexibility to work on a different topic meeting the topic criteria (that it will be related to the ELL or ELT discipline and it will be a debatable topic). Following are some sample discipline-specific argumentative topics that can be offered:

Table 2. Sample ELL and ELT argumentative topics

$$
\text { Sample ELL argumentative topics }
$$

Is cultural background linked to reading habits?

How does social media impact adolescences' interest in literature: positively or negatively?

Does literary instruction have a function of ethical enterprise?

To what extent do individuals' reading habits shape their identity development?

What factor has a bigger role in children's reading habits: teacher encouragement or parental encouragement?

Which one develops students' academic success better: out-of-school reading or school-related reading?

Is it possible to change the perceptions of a person who self-identifies themselves as a poor reader?

\section{Sample ELT argumentative topics}

Which one has a more important role in second language learning: intrinsic or extrinsic motivation? Which one should be the priority of teachers when teaching English to second language learners: accurate pronunciation or fluent speech? Should non-native speakers teach pronunciation? What type of feedback is the most effective in supporting students' language development: teacher feedback, peer feedback or automated feedback from computer programs?

Which is a more influential factor in second language learning: exposure to language or interaction with language users?

Is using L1 when teaching English as a foreign language a strategy or a problem?

Are children better learners than adults in terms of successful second language learning?
RumeliDE Dil ve Edebiyat Araştırmaları Dergis Osmanağa Mahallesi, Mürver Çiçeği Sokak, No:14/8 Kadıköy - İSTANBUL / TÜRKIYE 34714 tel: +90 505 7958124, +90 2167730616
Address

RumeliDE Journal of Language and Literature Studies

Osmanağa Mahallesi, Mürver Çiçeği Sokak, No:14/8

Kadıköy - ISTANBUL / TURKEY 34714

e-mail: editor@rumelide.com,

phone: +90 $5057958124,+902167730616$ 
Materials for argumentative essay writing can be developed by the course instructor using published research articles from the ELL and ELT disciplines. Sample argumentative essays can be created based on existing studies on disciplinary topics. Students can first study the structure of an argumentative essay by close examining of sample argumentative essays.

\section{SAMPIE ARGUMISNW BWIVE BSSAY}

\section{GUIDING OUESTIONS}

\section{Learning styles: \\ A controversy in second language acquisition}

Learners have been classified into different in terms of how learn for a long time. A learning style is a "natural, habitual and preferred way" of gaining new information (Reid, 1995). For example, learners can be visual learners who like leaming from visual stimuli or kinesthetic learners who like moving around and do not feel comfortable sitting at a desk for a very long time (Oxford, 2003). Such stylistic differences between learners have also been confirmed for second language learning. Some believe that connecting how we teach to learners preferred ways of learning can enhance students language learning. However, tailoring language instruction according to students' learning styles is practically not possible.

In the field of second language teaching, several researchers have investigated leamers'styles, which shows that style-specific instruction is no practical. Hyland (1993), for example, showed that Japanese students did not exhibit any major learning styles, but multiple minor learning styles. English language leamers can have several of the following leaming styles: global or analytic, field-dependent or field-independent, feeling or thinking impulsive or reflective, intuitive-randorm or concrete-sequential, closureoriented or open, extroverted or introverted; and visual, auditory, tactile or kinesthetic (Oxford et al. 1992). In such a case, how would a teacher be able to teach in a way that addresses several minor learning styles of the students? Even when students have distinct major learning styles, tailoring instruction accordingly is practically not realistic. As Pashler et al. (2008) discuss, would tailoring instruction mean grouping students by learning style and then giving customized instruction to each group? This would require additional teacher training and also increasing the number of teachers since the same teacher would not be able to teach to all groups at the same time. Much of the literature on learning styles in the field of second language focuses more on the fact that students' learning styles should be assessed and on the ways of how this assessment can be done than on how L2 instruction can be attuned specifically to students' learning styles. Teaching suggestions simply suggest incorporating materials addressing different sensory preferences such as visual or audio or grouping students as extroverts or introverts. But what about all the other different dimensions of learning styles? It is very difficult to address them all when teaching.

Learning is certainly multidimensional, and learners are certainly not the same in terms of how they learn. Although some believe that we should recognize the language learning differences between students, practically we carnot. Educational psychologists ask: "If every student is unique, how can teachers draw on their experiences with other students to improve the instruction of this particular student?" (Willingham, Hughes, \& Dobolyi, 2015). Language teaching can be more effective if teachers address the commonalties among language students rather than their differences.
- What is the topic?

- What is the author's argument about the topic?

- How are ideas organized throughout the introduction?

- Is any definition given? What is defined?

- Is a counter-argument given? What is it?

- How many sources are cited within the introduction? For what purposes?

- How are ideas organized throughout the body?

- How does the body start and end? With what ideas?

- Is the author's argument re-stated?

- How many sources are cited within the body? For what purposes?

- What pieces of evidence are presented to support the author's argument?

- Are any examples given? For what purposes?

- Are any explanations given? For what purposes?

- How are ideas organized

throughout the conclusion?

- Is the author's argument re-stated?

- Is a counter-argument re-given?

- Are the main points summarized?

- How is the text ended?

- What final comments are offered?

Figure 1. Sample argumentative essay on a topic from ELT and guiding analysis questions

Adres
RumeliDE Dil ve Edebiyat Araştırmaları Dergisi Osmanağa Mahallesi, Mürver Çiçeği Sokak, No:14/8 Kadıköy - ISTANBUL / TURKIYE 34714 e-posta: editor@rumelide.com tel: +90 5057958124, +90 2167730616
Address

RumeliDE Journal of Language and Literature Studies

Osmanağa Mahallesi, Mürver Çiçeği Sokak, No:14/8

Kadıköy - ISTANBUL / TURKEY 34714

e-mail: editor@rumelide.com,

phone: +90 505 7958124, +90 2167730616 
Towards teaching undergraduate-level disciplinary writing in English majors: A genre-based approach / A. Sarıcaoğlu (pp. 1024-1038)

In addition to class discussions about the topics of the sample essays, students can be engaged in close analysis tasks through some guiding questions related to the disciplinary topic, the author's argument, counterarguments, evidence presented to support the argument, the organization of ideas across paragraphs, citations, etc. A sample argumentative essay developed on a topic from the ELT discipline (i.e., learning styles) as well as the guiding questions for its analysis are presented in Figure 1. A sample literary analysis as well as the guiding questions are presented in Figure 2.

\section{SAMPIE HWERARY ANALYSIS}

\section{Feminism in Doris Lessing's "To Room Nineteen"}

Doris Lessing is one of the most controversial woman writers of our time. Although Lessing herself does not consider her writing to be feminist, she is regarded as one of the early voices of the feminist movement. As in several of her works, feminism is visible in her short story "To Room Nuneteen" which was published in 1963 in the collection "A. Man and Two Women" " To Room Nineteen" is based on the story of Susan Rawlings, a middle-aged woman married with four children, who comunits suicide. Lessing's story is a good example of the gendered division of labor, which is central to the feminist discourse of victimization.

At the beginning of Lessing's story "To Room Nineteen," Susan Rawlings is in her late twenties, works at a well-paid job and is a social happy woman with a rich sense of humor (p. 2302). Then she meets Matthew, gets married, quits her job and becomes the mother of four children. Susan and Matthew are perceived as an ideal couple as the narrator describes their relationship: "Not only they, but others, felt they were well matched" (p. 2301). At the beginning of their marriage, Susan willingly adopts her new culturally-and socially defined identity of the ideal wife and mother who leaves her job without questioning her situation. However, in the long tum, Susan is lost in the chaos of housework and in her roles as a mother and a wife and she loses her self-identity. The "unfair division of labor in patriarchal middle-class family turns out to be a trap, and Lessing shows that in fact, it is the family ideal they follow that brings the downfall of their relationship" (Özyurt Kilıç. 2017).

To Room Nineteen" was published "when the feminist movement was in its climax" (Zhao. 2012. p. 1654). This was a period when women were looking for their lost self and freedom. Room Nineteen was where Susan escaped to from housework, children, her unfaithful husband and the patriarchal system and where she found her lost self and freedom: "she went to the window. stretching her arms, smiling treasuring her anonymity, to look out. She was no longer Susan Rawlings, mother of four, wife of Matthew..... She no longer was mistress of the big white house and garden, owning clothes suitable for this and that activity or occasion. She was Mrs. Jones, and she was alone, and she had no past and no future."

Lessing "s "To Room Nineteen" displays a number of themes specific to the feminist movement: socially-and culturally-imposed roles for women, th psychological dimensions of mothering. male-female relationships, women's inner experiences, and forced roles and identities. Susan's death at the end as a result of a failed marriage is not seen as a defeat, but her way of resisting her culturally enforced image of mother and wife (Quawas. 2007).

\section{GUIDING QUESTIONS}

- What is the literary work analyzed?
- Who is the author?
- What information is given regarding
the author?
- What information is given regarding
the literary work?
- What is the author's interpretative
- What is the author's point of analysis?
- Is there a connection to a literary
theory? Which one?
- How are ideas organized throughout
the introduction?
- How are ideas organized throughout
the body?
- How does the body start and end?
- Is the author's interpretative argument
re-stated? Where?
- Is there a brief summary of the literary
work?
- How many outside sources are cited?
Why does the author make citations
- Is the author's interpretative argument
- Wrom these sources?
- Hhat pieces of evidence are
presented to support the author's
interpretative argument?
- Are there any references to the literary
work itself? Why does the author use
these references?
- Is there a connection to the literary
theory used?
- Hown
-

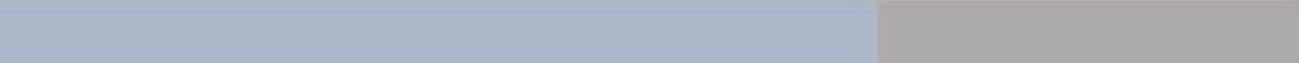

Figure 2. Sample literary analysis and guiding analysis questions

RumeliDE Dil ve Edebiyat Araşttrmaları Dergisi Osmanağa Mahallesi, Mürver Çiçeği Sokak, No:14/8 Kadıköy - ISTANBUL / TÜRKIYE 34714 e-posta: editor@rumelide.com tel: $+905057958124,+902167730616$
Address

RumeliDE Journal of Language and Literature Studies

Osmanağa Mahallesi, Mürver Çiçeği Sokak, No:14/8

Kadıköy - ISTANBUL / TURKEY 34714

e-mail: editor@rumelide.com

phone: +90 5057958124, +90 2167730616 


\subsection{Assessment}

When teaching academic writing skills, it is important to provide students with detailed information about their task performance so as to inform the improvement of their writing skills and their performance in future tasks. For this reason, an analytic scoring rubric with sub-categories addressing different aspects of writing, such as content, organization, and use of language can be used for evaluating students' written work in the disciplinary writing course. Applying the several criteria in an analytic rubric to students' written texts is time-consuming for the teacher; however, the advantages that analytic scoring has over holistic scoring (i.e., detailed feedback in different aspects of writing and more reliable and objective scoring (Weigle, 2002)) are important and worth the time and effort. Table 3 presents a sample rubric that can be used for evaluating students' ELL/ELT argumentative essays.

Table 3. Sample analytic rubric for evaluating ELL/ELT argumentative essays

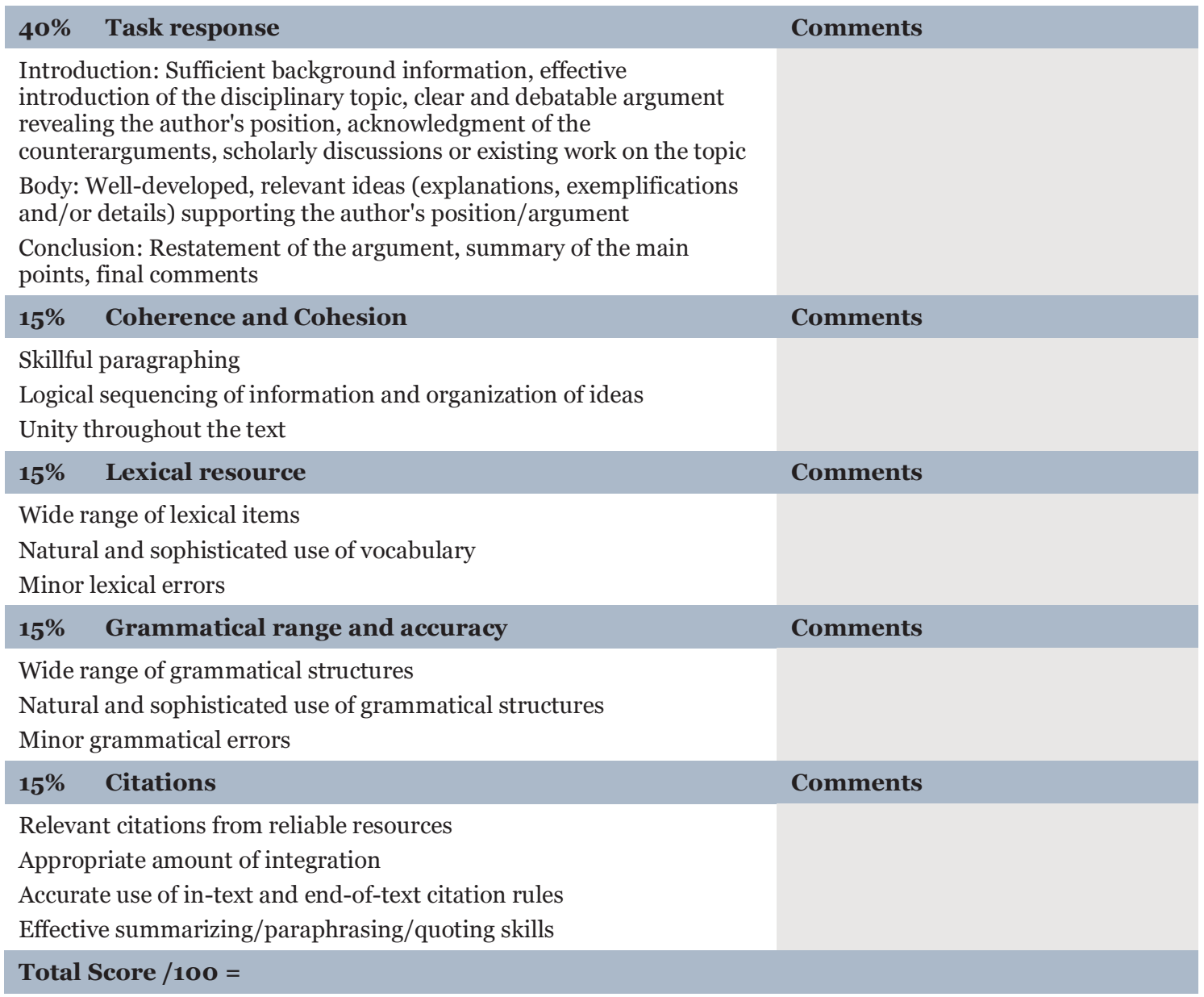

The same rubric can be used for the evaluation of all writing tasks by just changing the task response component. For example, to evaluate students' literary analyses, the following criteria can be included in the task response component based on the literature on literary analysis and teaching literary analysis (Lewis \& Ferretti, 2011; Ong, 2016; Uzun \& Topkaya, 2020):

Introduction: Sufficient background information, effective introduction to the literary analysis, introduction of the literary work and the author (if available), very brief summary of the literary work

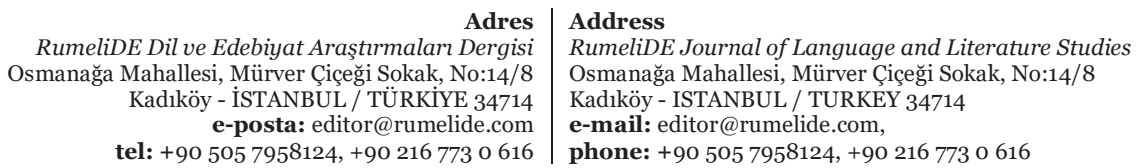


1036 / RumeliDE Journal of Language and Literature Studies 2022.26 (February)

Towards teaching undergraduate-level disciplinary writing in English majors: A genre-based approach / A. Sarıcaoğlu (pp. 1024-1038)

(either in introduction or body), clear and debatable interpretative argument revealing the author's perspective, clear point of analysis, a clear connection to the literary theory used, acknowledgment of scholarly discussions or existing work on the topic (if available)

Body: Evidence (reasons) to support the interpretative argument, careful and thorough examination of the literary work through specific references to the literary work and their explanations and references to other scholarly work, identification of repeated patterns in the literary work that lead to the argument

Conclusion: Restatement of the interpretative argument, summary of the main points, final comments

\section{Conclusions}

Generic academic writing courses offered within the departmental curricula of ELL and ELT programs do not seem to be adequately preparing students for their departmental writing tasks. Instead of a generic writing course, this study argues for a discipline-specific, research-informed, and genre-based writing course for the undergraduate-level students of ELL and ELT programs. Such a course would have a much higher potential to support increasing students' awareness of their disciplines and developing their knowledge of disciplinary content, knowledge of disciplinary genres, and disciplinary writing skills. To this end, this study described the development of an undergraduate level disciplinary writing course for ELL and ELT students. The course covers two general academic literacy skills (i.e., source-based writing and argumentation) and three genre-based writing skills (i.e., reflective writing, argumentative essay writing, and literary analysis/criticism writing). Course objectives, course units, weekly structuring of the course, sample teaching and learning activities and materials, and ideas for formative assessment of students' learning were shared.

The main purpose of this study is to contribute to a better understanding of how we can support the academic writing needs of undergraduate students in ELL and ELT programs. With regard to genrebased disciplinary writing, seldom does one-size-fits-all approach work. Thus, the feasibility of this course needs to be evaluated by course instructors for their specific contexts taking into account program-specific features such as the level of their students, the number of academic writing courses offered in their departments, the specific writing tasks students perform for their departmental coursework, etc.

Teaching disciplinary writing skills is not easy for writing instructors as it demands expertise and experience in two domains: ELL/ELT and genre-based academic writing. I am able to design this course because I am a faculty member working in an ELL program with expertise in ELT, in particular L2 writing, as well as experience in teaching academic writing in several different contexts for several years. During the process of developing this course, I personally experienced the challenge posed by the limited availability of pedagogical resources that we can use to teach disciplinary writing skills to ELL/ELT students, except a few studies that share some instructional ideas and assessment rubrics (see Lewis and Ferretti (2011) and Uzun and Topkaya (2020)). For this research-informed course, we, as instructors, must also play the role of material-developer, making use of published research studies with lots of modification, in particular simplification for first-year students. On the part of the teacher, this course is hard work, requiring resources of time and intellect. However, there is value in supporting students' development of disciplinary content knowledge and writing skills starting at an early stage in their undergraduate studies, thus it is worth the time and effort invested.

Because the disciplinary writing course proposed in this study is newly developed, practitionerresearchers in ELL or ELT programs who choose to implement it should investigate its strengths and

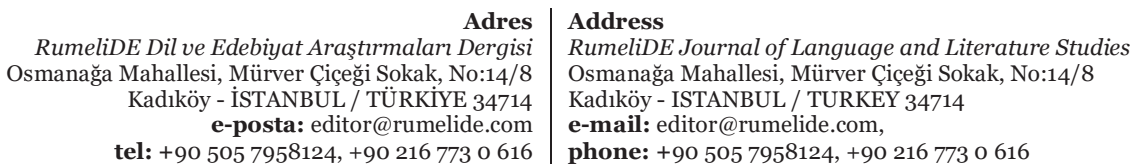


weaknesses to maximize its effectiveness. Utilizing a pre-test/post-test design assessing students' disciplinary writing skills before and after receiving instruction will be a good way for such examinations (see Chen and $\mathrm{Su}$ (2011) and Uzun and Topkaya (2020) for example studies). Benefiting from qualitative data is also valuable for gaining insights into students' perceptions and supporting the quantitative findings. Researchers should also consider longitudinal studies on the effectiveness and impact of discipline-based writing courses for ELL and ELT students.

\section{References}

Altınmakas, D., \& Bayyurt, Y. (2019). An exploratory study on factors influencing undergraduate students' academic writing practices in Turkey. Journal of English for Academic Purposes, 37, $88-103$.

Andrews, R. (2010). Argumentation in higher education: Improving practice through theory and research. New York, NY: Routledge.

Andrews, R. (2015). Critical thinking and/or argumentation in higher education. In M. Davies \& R. Barnett (Eds.)., The Palgrave Handbook of Critical Thinking in Higher Education (pp. 49-62). New York, NY: Palgrave Macmillan.

Baik, C., \& Greig, J. (2009). Improving the academic outcomes of undergraduate ESL students: The case for discipline-based academic skills programs. Higher Education Research \& Development, 28(4), 401-416.

Bressler, C.E. (2010). Literary criticism: An introduction to theory and practice (5th ed.). New York: Longman.

Cargill, M., Xin, G., Xiaoqing, W., \& O’Connor, P. (2018). Preparing Chinese graduate students of science facing an international publication requirement for graduation: Adapting an intensive workshop approach for early-candidature use. English for Specific Purposes, 52, 13-26.

Chen, Y-S., \& Su, S-W. (2011). A genre-based approach to teaching EFL summary writing. ELT Journal, 66(2), 184-192.

Cheng, A. (2008). Analyzing genre exemplars in preparation for writing: The case of an L2 graduate Student in the ESP genre-based instructional framework of academic literacy. Applied Linguistics, 29(1), 50-71.

Cheng, G. (2017). The impact of online automated feedback on students' reflective journal writing in an EFL course. The Internet and Higher Education, 34, 18-27.

Cumming, A., Lai, C., \& Cho, H. (2016). Students' writing from sources for academic purposes: A synthesis of recent research. Journal of English for Academic Purposes, 23, 47-58.

Derewianka, B., M. (2003). Trends and issues in genre-based approaches. RELC Journal, 34, 133-154.

Fernsten, L. A., \& Reda, M. (2011). Helping students meet the challenges of academic writing. Teaching in Higher Education, 16(2), 171-182.

Flowerdew, J. (2000). Discourse community, legitimate peripheral participation, and the nonnativeEnglish-speaking scholar. TESOL QUARTERLY, 34(1), 127-150.

Geiser, S., \& Studley, R. (2002). UC and the SAT: Predictive validity and differential impact of the SAT I and SAT II at the University of California. Educational Assessment, 8(1), 1-26.

Gimenez, J. (2008). Beyond the academic essay: Discipline-specific writing in nursing and midwifery. Journal of English for Academic Purposes, 7(3), 151-164.

Johns, A. M., \& Swales, J. M. (2002). Literacy and disciplinary practices: Opening and closing perspectives. Journal of English for Academic Purposes, 1, 13-28.

Hatton, N., \& Smith, D. (1995). Reflection in teacher education: Towards definition and implementation. Teaching and Teacher Education, 11(1), 33-49.

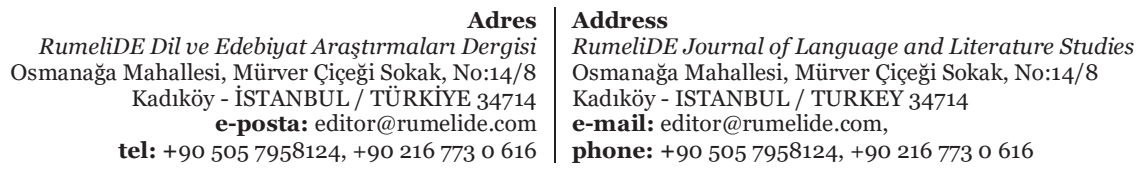


1038 / RumeliDE Journal of Language and Literature Studies 2022.26 (February)

Towards teaching undergraduate-level disciplinary writing in English majors: A genre-based approach / A. Sarıcaoğlu (pp. 1024-1038)

Hyland, K. (2000). Disciplinary discourses: Social interactions in academic writing. Harlow: Longman.

Hyland, K. (2007). Genre pedagogy: Language, literacy and L2 writing instruction. Journal of Second Language Writing, 16(3), 148-64.

Kamasak, R., Sahan, K., \& Rose, H. (2021). Academic language-related challenges at an English-medium university. Journal of English for Academic Purposes, 49, 100945.

Kutevaa, M. (2013). Graduate learners' approaches to genre-analysis tasks: Variations across and within four disciplines. English for Specific Purposes, 32, 84-96.

Lai, G., \& Calandra, B. (2010). Examining the effects of computer-based scaffolds on novice teachers' reflective journal writing. Educational Technology Research and Development, 58(4), 421-437.

Lave, J., \& Wenger, E. (1991). Situated learning: Legitimate peripheral participation. Cambridge: Cambridge University Press.

Lewis, W. E., \& Ferretti, R. P. (2011). Topoi and literary interpretation: The effects of a critical reading and writing intervention on high school students' analytic literary essays. Contemporary Educational Psychology, 36(4), 334-354.

Li, Y. (2006). Negotiating knowledge contribution to multiple discourse communities: A doctoral student of computer science writing for publication. Journal of Second Language Writing, 15(3), 159-178.

Marshall, J. (2000). Research on response to literature. In R. Barr, M.L. Kamil, P. Mosenthal, \& P.D. Pearson (Eds.), Handbook of reading research, Vol. III (pp. 381-402). Mahwah, NJ: Lawrence Erlbaum Associates Inc.

Mei, W. S. (2006). Creating a contrastive rhetorical stance: Investigating the strategy of problematization in students' argumentation. RELC Journal, 37, 329-353.

Mitchell, S., \& Riddle, M. (2000). Improving the quality of argument in higher education: Final Report. School of Lifelong Learning and Education: Middlesex University.

Ong, W. A. (2016). Using genre-based writing instruction to teach the writing of literary criticism. GEMA Online ${ }^{2}$ Journal of Language Studies, 16(1), 35-48.

Pasternak, D. L., \& Rigoni, K. K. (2015). Teaching reflective writing: Thoughts on developing a reflective writing framework to support teacher candidates. Teaching/Writing: The Journal of Writing Teacher Education, 4(1), 93-108.

Penso, S., Shoham, E., \& Shiloah, N. (2001). First steps in novice teachers' reflective activity. Teacher Development, 5(3), 323-338.

Persky, H. R., Daane, M. C., \& Jin, Y. (2003). The nation's report card: Writing 2002, NCES 2003. Washington, DC: National Center for Educational Statistics.

Swales, J. M. (1990). Genre analysis: English in academic and research settings. Cambridge: Cambridge University Press.

Uzun, K., \& Topkaya, E. Z. (2020). The effects of genre-based instruction and genre-focused feedback on L2 writing performance. Reading \& Writing Quarterly, 36(5), 438-461.

Weigle, S. C. (2002). Assessing writing. Cambridge, UK: Cambridge University Press.

Wette, R. (2019). Embedded provision to develop source-based writing skills in a Year 1 health sciences course: How can the academic literacy developer contribute? English for Specific Purposes, 56, $35-49$.

Wingate, U. (2012). 'Argument!' helping students understand what essay writing is about. Journal of English for Academic Purposes, 11(2), 145-154.

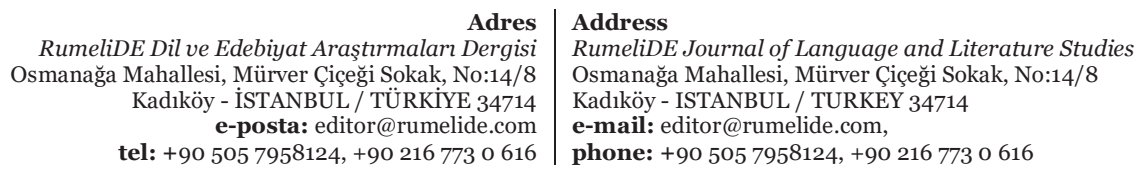

